

\section{DISCLAIMER}

This report was prepared as an account of work sponsored by an agency of the United States Government. Neither the United States Government nor any agency Thereof, nor any of their employees, makes any warranty, express or implied, or assumes any legal liability or responsibility for the accuracy, completeness, or usefulness of any information, apparatus, product, or process disclosed, or represents that its use would not infringe privately owned rights. Reference herein to any specific commercial product, process, or service by trade name, trademark, manufacturer, or otherwise does not necessarily constitute or imply its endorsement, recommendation, or favoring by the United States Government or any agency thereof. The views and opinions of authors expressed herein do not necessarily state or reflect those of the United States Government or any agency thereof. 


\section{DISCLAIMER}

Portions of this document may be illegible in electronic image products. Images are produced from the best available original document. 


Printed in USA. Price $\$ 0.75$
Office of Technical Services
Department of Commerce
Washington 25, D.C.
LEGAL NOTICE
This report was prepared as an account of Government sponsored work. Neither the United States,
nor the Commission, nor any person acting on behalf of the Commission:
A. Makes any warranty or representation, expressed or implied, with respect to the accuracy,
completeness, or usefulness of the information contained in this report, or that the use of
any information, apparatus, method, or process disclosed in this report may not infringe
privately owned rights; or
B. Assumes any liabilities with respect to the use of, or for damages resulting from the use of
any information, apparatus, method, or process disclosed in this report.
As used in the above, "person acting on behalf of the Commission" includes any employee or
contractor of the Commission, or employee of such contractor, to the extent that such employee
or contractor of the Commission, or employee of such contractor prepares, disseminates, or
provides access to, any information pursuant to his employment or contract with the Commission,
or his employment with such contractor.


ORNL-2892

Contract No. W-7405-eng-26

OPERATIONS DIVISION

SURFACE TEMPERATURES OF IRRADIATED ORR FUEL

ELEMENTS COOLED IN STAGNANT AIR

J. F. Wett, Jr.

DATE ISSUED

APR $6 \quad 1960$

OAK RIDGE NATIONAL LABORATORY

Ook Ridge, Tennessee

operated by

UNION CARBIDE CORPORATION for the

U.S. ATOMIC ENERGY COMMISSION 
THIS PAGE

\section{WAS INTENTIONALLY \\ LEFT BLANK}




\section{CONTENTS}

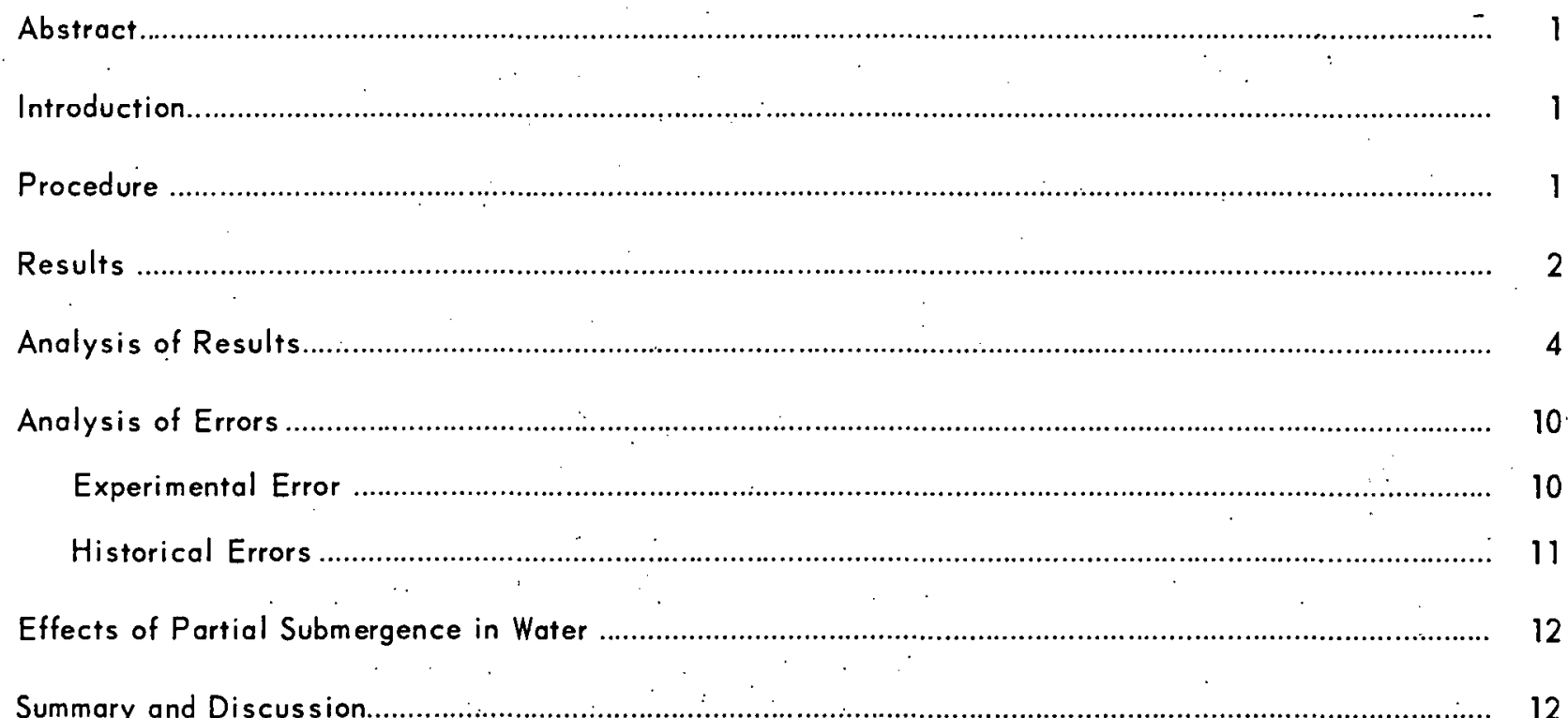




\title{
SURFACE TEMPERATURES OF IRRADIATED ORR FUEL ELEMENTS COOLED IN STAGNANT AIR
}

\author{
J. F. Wett, Jr.
}

\begin{abstract}
A problem which arises during shipment of irradiated fuel elements is that of the maximum surface temperature which might be reached when the element is air-cooled by natural convection only. In an attempt to answer this problem, several irradiated Oak Ridge Research Reactor (ORR) fuel elements were raised into a hot cell, and their temperature traverses were measured.

Correlations between maximum surface temperature and the irradiation history of the element were made by using the Way-Wigner formula and the data of Perkins and King. It can be concluded that a decay of $19 \mathrm{hr}$ is sufficient to keep the maximum surface temperature of an ORR fuel element, in air, below a dangerous level.

It is felt that the results of this investigation, while not directly applicable to elements other than those from the ORR, can assist in establishing orders of magnitude and will provide a basis for more generalized extensions.
\end{abstract}

\section{INTRODUCTION}

During the period July-October 1959 an investigation was conducted to determine the relation between the irradiation history and the maximum surface temperature of an irradiated ORR (Oak Ridge Research Reactor) fuel element suspended in stagnant air. The problem of excessive fuel plate temperature is most likely to occur during shipping; hence it is somewhat academic for ORR elements, since they remain in the storage pool for a considerable decay period before shipment to a reprocessing area. However, there are reactors with elements similar to those in the ORR where the problem is far from academic, because decay in a pool may not be feasible for economic or technical reasons. It is felt that the results of this investigation, while not directly applicable to elements other than those from the ORR, can assist in establishing orders of magnitude and will provide a basis for more generalized extensions.

\section{PROCEDURE}

A two-fingered probe was used to obtain surface temperatures of the interior plates. The probe consisted of two aluminum tubes into which thermocouples were placed. After the couples were in place, the tubes were flattened in order to provide a good friction fit in a coolant channel. The probes were held together by an aluminum spacer which also provided a fitting for the long rod used in placing the probe in the element.
The south hot cell at the ORR was used for this experiment. The construction of the cell is such that an element being brought from the reactor pool must be passed under the west wall of the cell before being suspended on the cell crane hook. Thus, the thermocouple probe had to be placed in the element while the element was still in the pool. The thermocouple leads had to run from the instruments on the balcony, into the pool, and under the hot-cell wall. This required leads approximately $50 \mathrm{ft}$ long and required that they be waterproofed. The aluminum tubing was continued to the top of the end boxes of the element, at which point the leads continued through Tygon tubing to the instruments. The Tygon was the weak point of the system for high-temperature elements, necessitating new probes and leads for each element. Figure 1 is a photograph of a fuel element suspended in the cell.

Since decay time is such an important parameter, severe restrictions are placed upon the time after a reactor fuel change during which data can be obtained. Further, the ORR runs on a three-week schedule, and that, combined with conflicting usage of the hot cell, places limitations upon the quantity of data which can be obtained in a reasonable time. Consequently, it was decided to limit the objective to obtaining a semiempirical relation between element irradiation history and maximum fuel plate surface temperature.

Since the magnitudes of the temperatures to be expected were unknown, it was necessary to start 


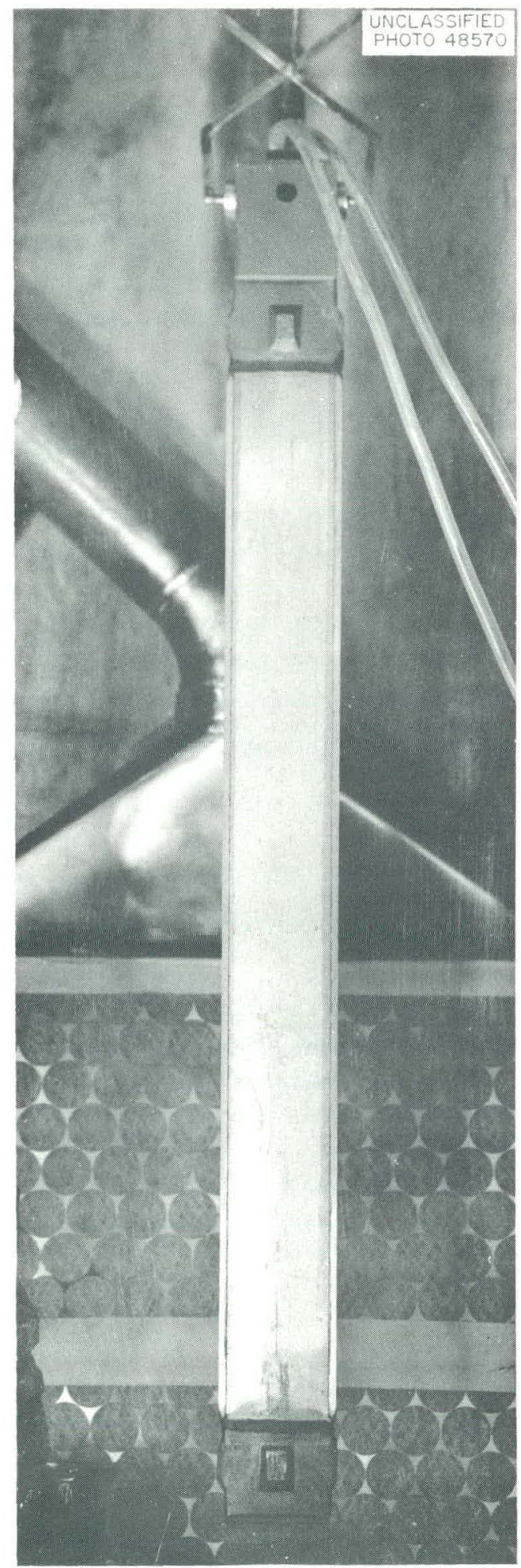

Fig. 1. Fuel Element Suspended in Cell. with elements whose decay times were long enough to assure reasonable temperatures. After a feel for the magnitudes was obtained, the decay times were shortened for each subsequent run.

For the first series of tests, one thermocouple was placed in each probe. One probe was placed $4 \mathrm{in}$. and the other $16 \mathrm{in}$. from the top of the fuel plate. For the second series, six thermocouples were used, three in each probe. They were placed nominally $2,6,10,14,18$, and $22 \mathrm{in}$. from the top of the fuel plate. The position of these couples was checked by use of a torch before they were put into use. For the first series of tests, mentioned above, both the temperatures were read on separate recorders. However, as knowledge of the transients was gained, all temperatures were read on a multipoint recorder. The ambient temperature of the hot cell was also taken. All elements were hung vertically.

Radiation through the cell at no time exceeded $\sim 30 \mathrm{mr} / \mathrm{hr}$. A more detailed report on the radiation aspect will be issued in the future.

\section{RESULTS}

Ten elements were raised into the hot cell. One of these was raised six times, one three times, and one twice, giving a total of 18 datum points. The irradiation history of the elements is shown in Table 1 , and the equilibrium temperatures reached by the variuus elements are shown in Table 2. The temperature of the hot cell was $90^{\circ} \mathrm{F}$.

Element OR-103 was left hanging in the hot cell over a weekend so that temperature decay data could be taken. After it had been suspended for approximately $30 \mathrm{hr}$ at a maximum surface temperature of $220^{\circ} \mathrm{F}$, two distinct jumps in activity were detected by a continuous air monitor which was monitoring the hot-cell air. Unfortunately, this occurred during the night, and analyses were not made. The element was then submerged as a safety precaution. Element OR-103 was subsequently reinserted in the reactor with no adverse effects. Figure 2 shows the temperature of OR- 103 at both 4 and $16 \mathrm{in}$. below the top of the fuel plate, plotted vs the decay time, and Fig. 3 shows the temperature transients. Not shown on Fig. 3 is the fact that the boiling point of the surface moisture could be clearly seen. It manifested itself as a slight pause in the transient. This was due to steam cooling of the thermocouple. 
Table 1. Irradiation History of Fuel Elements

\begin{tabular}{|c|c|c|c|c|c|c|c|c|c|c|c|}
\hline \multirow[b]{2}{*}{$\begin{array}{c}\text { Element } \\
\text { No. }\end{array}$} & \multicolumn{3}{|c|}{ Last Cycle Prior to Measurement } & \multicolumn{4}{|c|}{ Cycle Before Last Cycle } & \multicolumn{4}{|c|}{ Cycle Before Next to Lost Cycle } \\
\hline & $\begin{array}{l}\text { Irradiation } \\
\text { Time } \\
(\mathrm{hr})\end{array}$ & $\begin{array}{l}\text { Woight of } \\
U^{235} \text { of } \\
\text { Boginning } \\
\text { of Cycle } \\
\text { (g) }\end{array}$ & $\begin{array}{c}\text { Average } \\
\text { Flux }\end{array}$ & $\begin{array}{l}\text { Irrodiation } \\
\text { Time } \\
\text { (hr) }\end{array}$ & $\begin{array}{c}\text { Decoy } \\
\text { Time * } \\
\text { (hr) }\end{array}$ & $\begin{array}{l}\text { Weight of } \\
U^{235} \text { ot } \\
\text { Beginning } \\
\text { of Cyele } \\
\text { (g) }\end{array}$ & $\begin{array}{c}\text { Average } \\
\text { Flux }\end{array}$ & $\begin{array}{c}\text { Irradiation } \\
\text { Time } \\
(\mathrm{hr})\end{array}$ & $\begin{array}{c}\text { Decoy } \\
\text { Time* } \\
\text { (hr) }\end{array}$ & $\begin{array}{l}\text { Weight of } \\
U^{235} \text { of } \\
\text { Beginning } \\
\text { of Cycle } \\
\text { (g) }\end{array}$ & $\begin{array}{c}\text { Average } \\
\text { Flux }\end{array}$ \\
\hline & & & $\times 10^{14}$ & & & & $\times 10^{14}$ & & & & $\times 10^{14}$ \\
\hline 103 & 321 & 194.7 & 0.6 & 120 & 744 & 199.8 & 0.95 & & & & \\
\hline 87 & 321 & 193.7 & 1.2 & 120 & 744 & 200.3 & 1.23 & & & & \\
\hline 97 & $32 !$ & 143.2 & 1.1 & 120 & 744 & 116.1 & 0.74 & 312 & 1464 & 155.6 & 0.14 \\
\hline 94 & 144 & 150.7 & 1.04 & 264 & 540 & 164.2 & 1.2 & 120 & 1908 & 166.7 & 0.92 \\
\hline 82 & 200 & 173.5 & 0.91 & 100 & 679 & 176.2 & 0.92 & 300 & 906 & 182.3 & 0.53 \\
\hline 100 & 200 & 146.3 & 1.18 & 100 & 679 & 148.8 & 1.03 & 120 & 1289 & 153.5 & 1.15 \\
\hline 151 & 200 & 199.6 & 1.02 & & & & & & & & \\
\hline $87^{\star \star}$ & 417 & 176.5 & 0.87 & 321 & 747 & 193.7 & 1.2 & 120 & 1827 & 200.3 & 1.23 \\
\hline 158 & 417 & 200.0 & 0.75 & & & & & & & & \\
\hline 164 & 536 & 200.0 & 1.01 & & & & & & & & \\
\hline
\end{tabular}

* In oddition to decoy times given in Table 2.

* Second test.

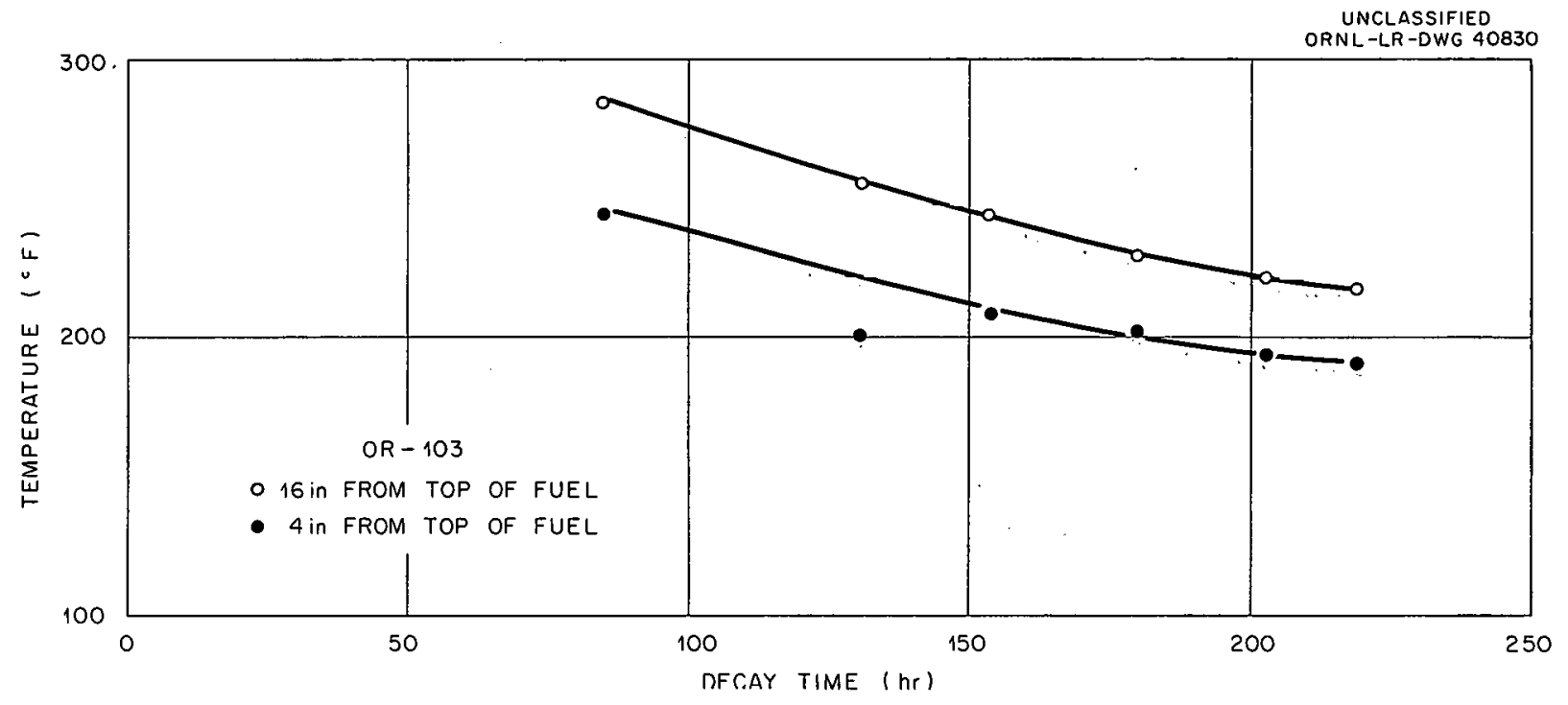

Fig. 2. Temperature of OR-103 at 4 and 16 in. Below Top of Fuel Plate.

Figure 4 is a more detailed trace of a transient and shows this point clearly. The transients of Fig. 3 are quite typical of all those recorded.

The first two elements monitored with the sixthermocouple probe were OR-158 and OR-87. Figure 5 shows the equilibrium tempcrature traverses of these elements. Notice that the hot spot of OR-87 is above the midplane of the length ("center line") rather than below, a result of inverting the element. ORR elements are symmetrical about their midplane, with respect to length, and are inverted during their lifetime to increase fuel burnup. The burnup of OR- 158 was measured by A. L. Colomb ${ }^{1}$ of the Operations

${ }^{1}$ Reactor Operations and Radioactive Waste Quarterly Report, July-September 1959, ORNL CF-59-9-111, p 24. 
Table 2. Equilibruim Temperatures of Irradiated Fuel Elements Cooled in Stagnant Air

\begin{tabular}{|c|c|c|c|c|c|c|c|}
\hline Element & $\begin{array}{c}\text { Decoy Time } \\
(h r)\end{array}$ & $\begin{array}{l}\text { Distance from } \\
\text { Top of Fuel } \\
\text { (in.) }\end{array}$ & $\begin{array}{c}\text { Measured } \\
\text { Temperature } \\
\left({ }^{\circ} \mathrm{F}\right)\end{array}$ & Element & $\begin{array}{c}\text { Decoy Time } \\
(h r)\end{array}$ & $\begin{array}{l}\text { Distance from } \\
\text { Top of. Fuel } \\
\text { (in.) }\end{array}$ & $\begin{array}{c}\text { Measured } \\
\text { Temperature } \\
\left({ }^{\circ} \mathrm{F}\right)\end{array}$ \\
\hline \multirow[t]{12}{*}{103} & 85 & 4 & 245 & 158 & 723 & 5.8 & 155 \\
\hline & 131 & 16 & 285 & & & 9.3 & 160 \\
\hline & 131 & 4 & 201 & & & 15.7 & 159 \\
\hline & & 16 & 256 & & & 19.4 & 157 \\
\hline & 154 & 4 & 209 & $87^{\star}$ & 723 & 2.5 & 189 \\
\hline & & 16 & 245 & & & 4.1 & 195 \\
\hline & 180 & 4 & 203 & & & 5.8 & 197 \\
\hline & & 16 & 230 & & & 9.3 & 201 \\
\hline & 203 & 4 & 195 & & & 15.7 & 193 \\
\hline & & 16 & 222 & & & 19.4 & 184 \\
\hline & 219 & 4 & 191 & 164 & 19.25 & 2.5 & 541 \\
\hline & & 16 & 218 & & & 4.1 & 558 \\
\hline \multirow[t]{4}{*}{87} & 104 & 4 & 312 & & & 5.8 & 593 \\
\hline & & 16 & 352 & & & 9.3 & 634 \\
\hline & 176 & 4 & 249 & & & 15.7 & 641 \\
\hline & & 16 & 302 & & & 19.4 & 620 \\
\hline \multirow[t]{2}{*}{97} & 108 & 4 & 298 & & 40.25 & 3.5 & 430 \\
\hline & & 16 & 341 & & & 6 & 465 \\
\hline \multirow[t]{2}{*}{94} & 780 & 4 & 153 & & & 14.5 & 518 \\
\hline & & 16 & 175 & & & 17.8 & 505 \\
\hline \multirow[t]{2}{*}{82} & 34 & 4 & 395 & & & 21.5 & 475 \\
\hline & & 16 & 473 & & 61 & 3.8 & 368 \\
\hline \multirow[t]{2}{*}{100} & 31 & 4 & 385 & & & 7.3 & 410 \\
\hline & & 16 & 440 & & & 11.5 & 438 \\
\hline \multirow[t]{2}{*}{151} & 28 & 4 & 366 & & & 13.3 & 450 \\
\hline & & 16 & 496 & & & 17.3 & 450 \\
\hline \multirow[t]{2}{*}{158} & 723 & 2.5 & 151 & & & 21.5 & 430 \\
\hline & & 4.7 & 154 & & & & \\
\hline
\end{tabular}

* Se cond test.

Division. The normalized fuel burnup is shown in Fig. 6. The point of maximum fuel burnup, that is, the point of maximum heat production, occurs approximately $1.5 \mathrm{in}$. below the midplane. The maximum temperature occurs approximately 0.75 in. below the midplane.

Figure 7 shows the temperature traverses for OR-164 for various decay times. In this case, the maximum temperature appears to be approximately $1.5 \mathrm{in}$. below the center line.

\section{ANALYSIS OF RESULTS}

As stated previously, the major objective of this work was to determine a semiempirical relation between maximum fuel-plate temperature and 


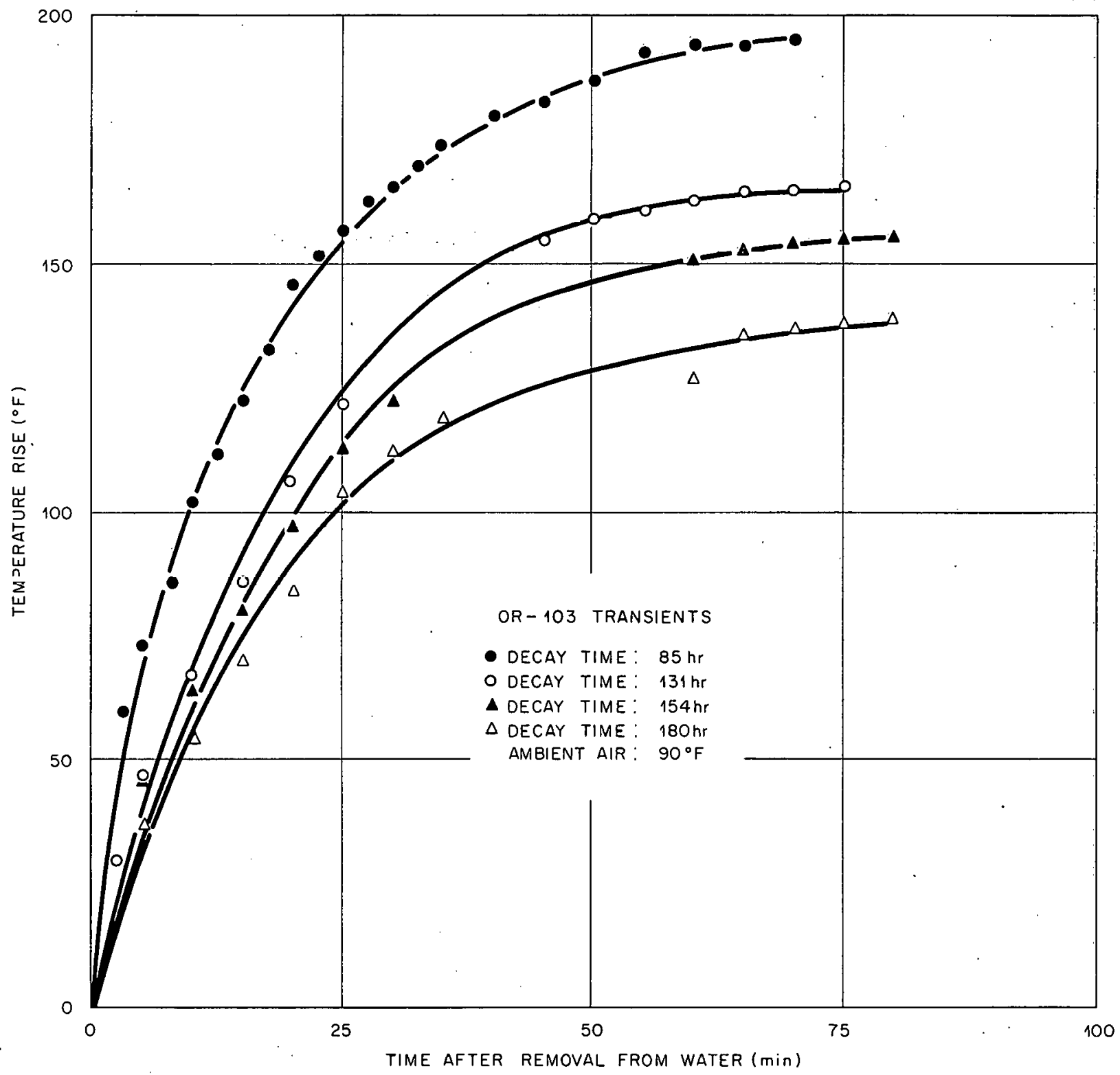

Fig. 3. Temperature Transients of OR-103.

the irradiation history of the element. The analysis was based on the maximum temperature difference between the surface of a fuel plate and the ambient air. The following assumptions are made:

1. All the heat is lost by convection.

2. The change in temperature of the air passing through the elements is small.
3. The heat transfer coefficient is constant. ${ }^{2}$

Then

$$
\theta=\frac{1}{b A} q
$$

2M. Jakob, Heat Transfer, vol 1, p 467, Wiley, New York, 1949. 


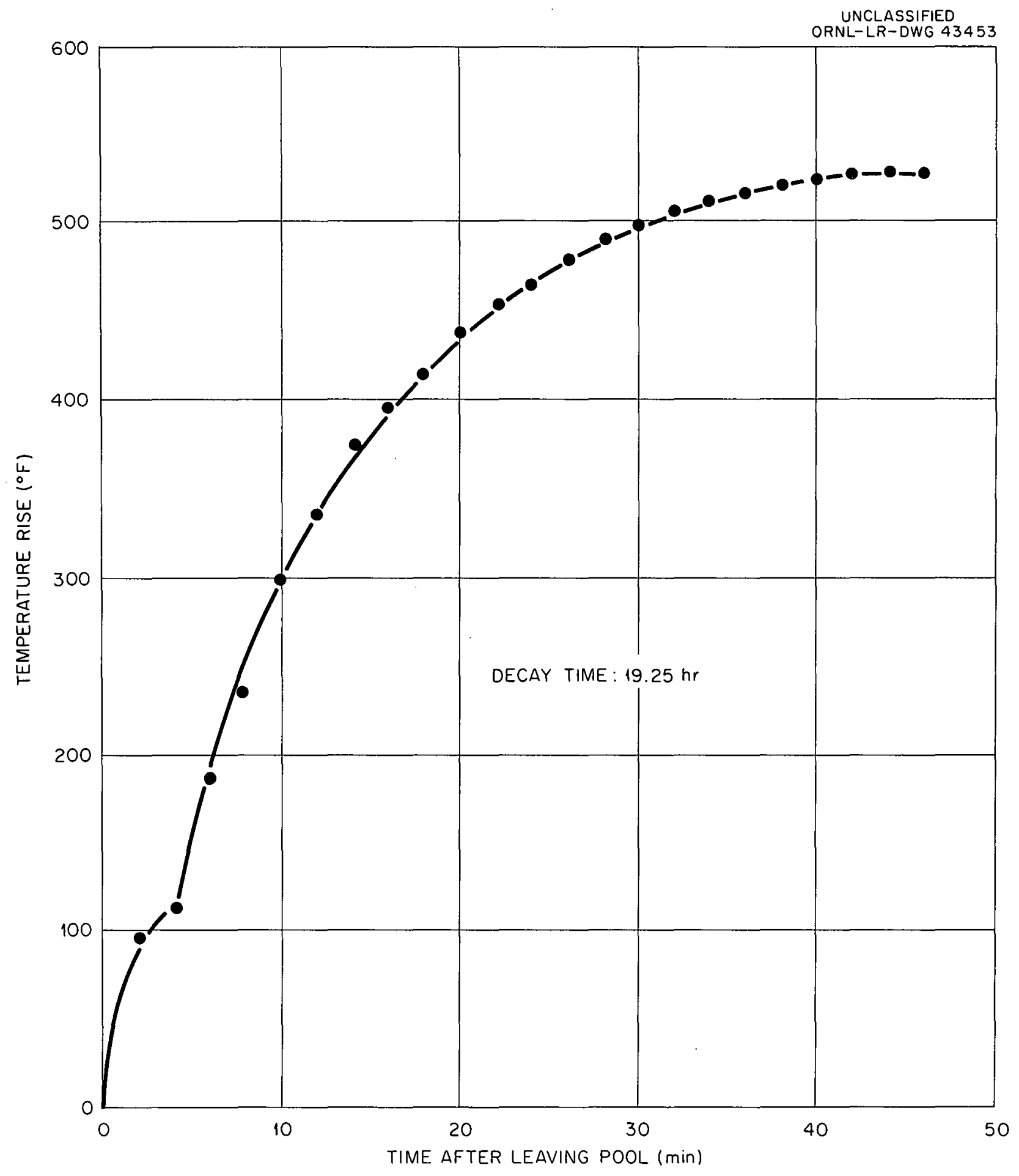

Fig. 4. Temperature Transient of OR-164 at Position 5 in. from Top of Element. Slight pause in transient was due to steam cooling of thermocouple. 


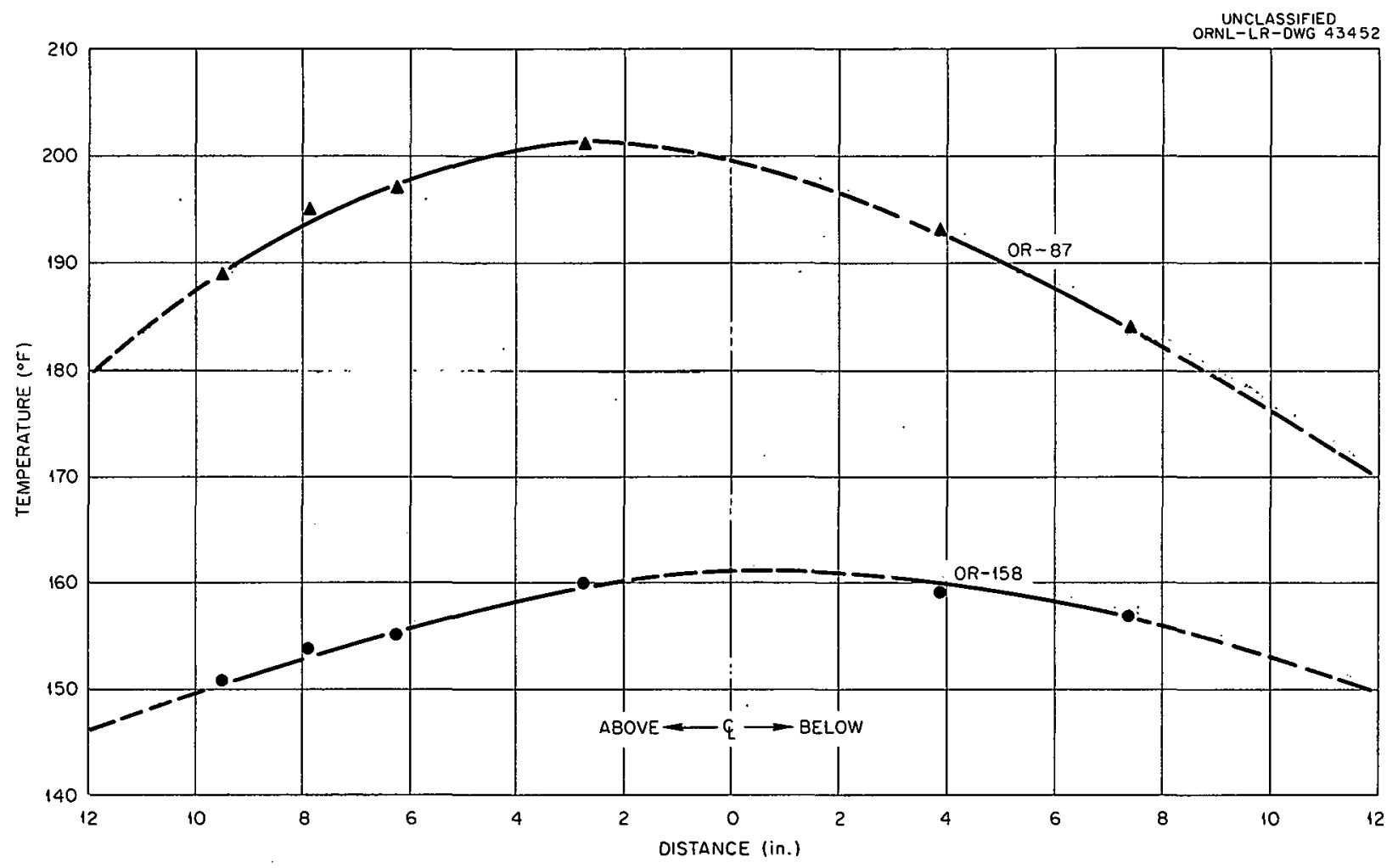

Fig. 5. Temperature Träverses for $O R=87$ and $O R-158$.

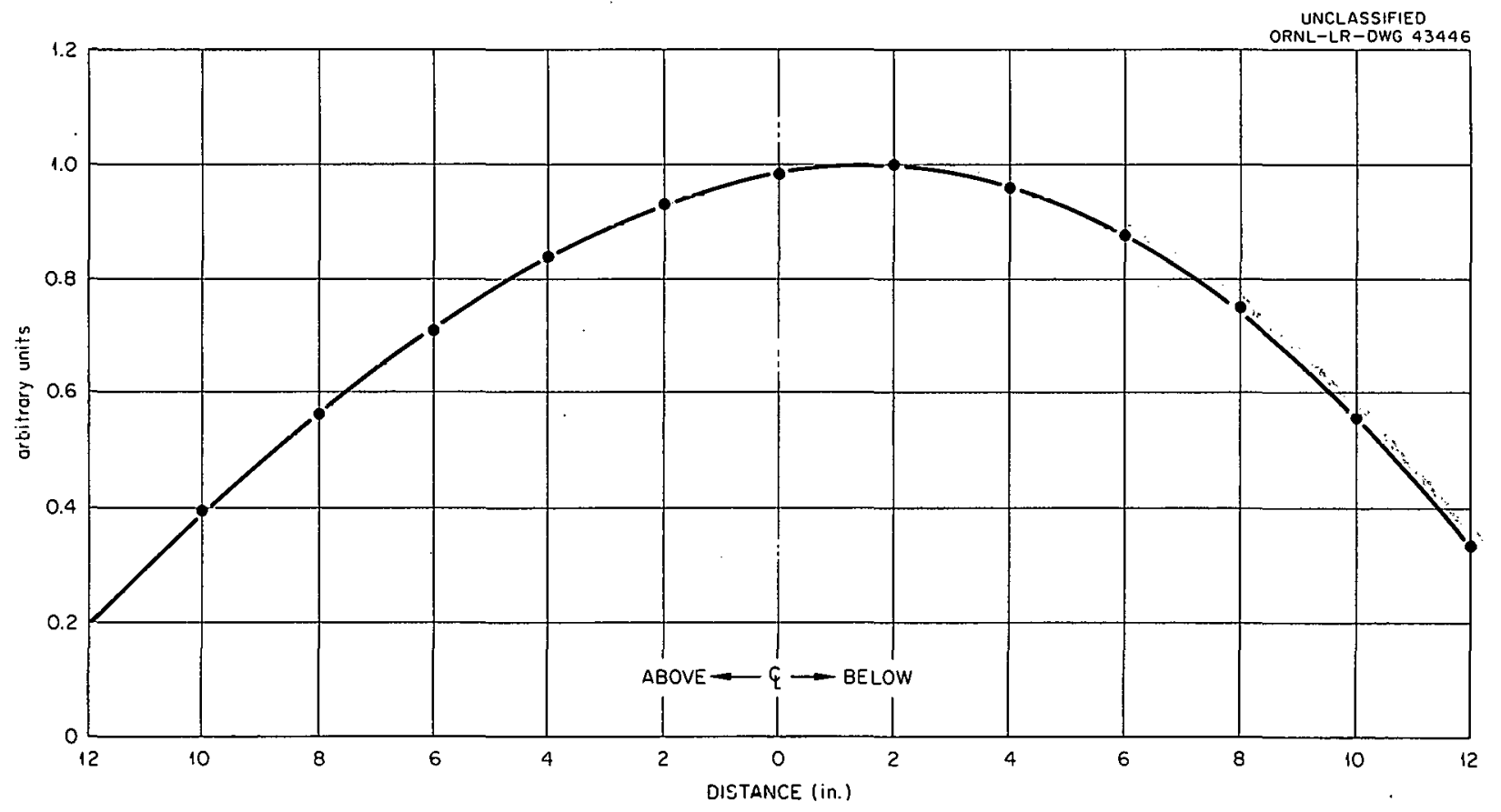

Fig. 6. Normalized Burnup Curve for OR-158. 


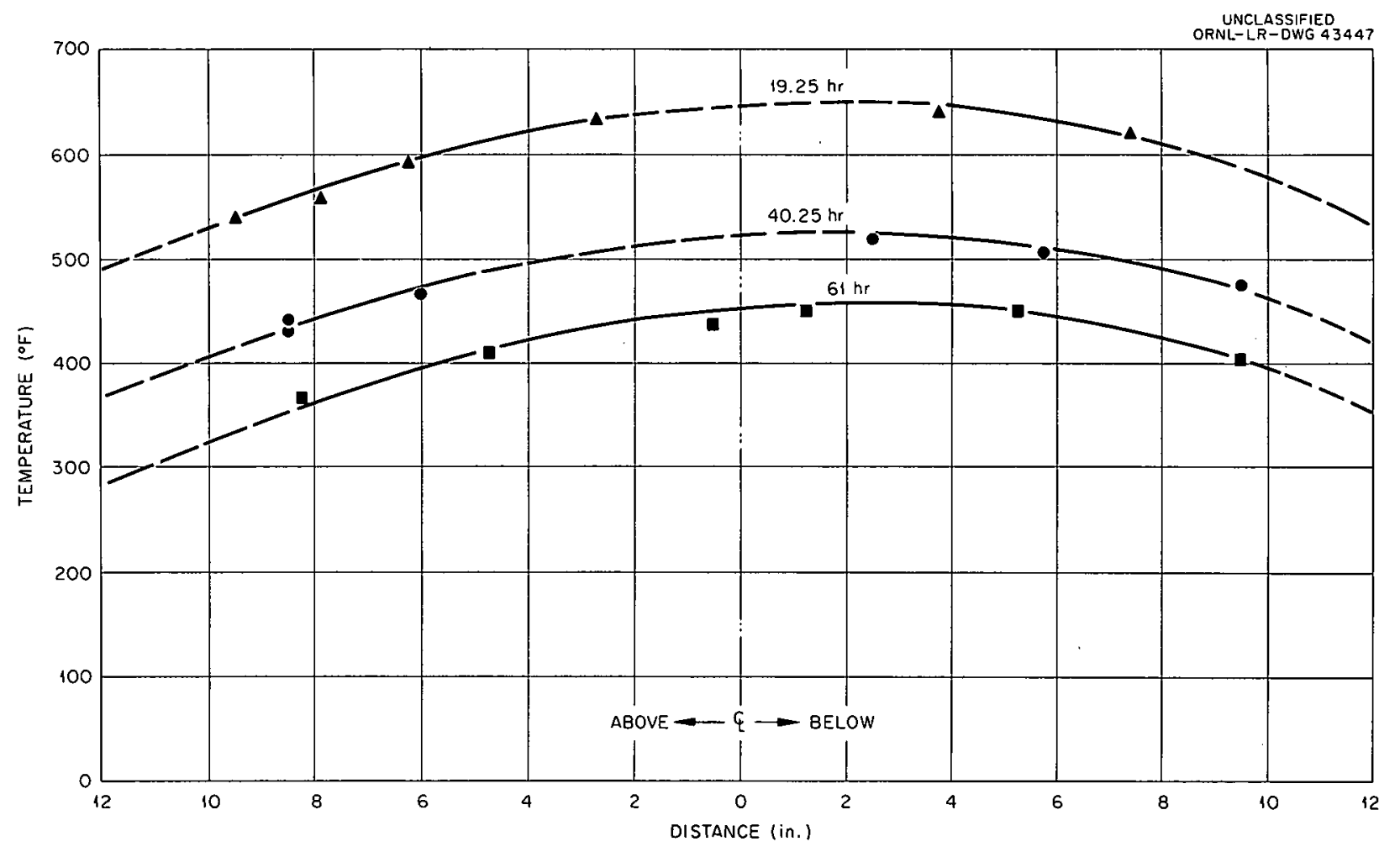

Fig. 7. Temperature Traverses for OR-164 for Various Decay Times.

where

$\theta=$ temperature difference between fuel plate

- surface and ambient air, ${ }^{\circ} \mathrm{F}$,

$b=$ heat transfer coefficient, Btu. $\mathrm{ft}^{-2} \cdot \mathrm{hr}^{-1} \cdot\left({ }^{\circ} \mathrm{F}\right)^{-1}$,

$A=$ fuel element heat transfer area, $\mathrm{ft}^{2}$,

$q=$ heat transfer from element, Btu/hr.

Now, the heat transferred from an element is proportional to the energy released by the decaying fission products; also, the area is a constant. Thus

$$
\theta=C Q ，
$$

where

$C=$ constant,

$Q=$ energy released by fission products.

There are at least two very convenient ways of calculating $Q$. One is the familiar Way-Wigner formula, ${ }^{3}$

$$
\frac{P}{P_{0}}=6.22 \times 10^{-2}\left[t^{-0.2}-(T+t)^{-0.2}\right] ，
$$

where

$$
\begin{aligned}
P_{0} & =\text { the operating power of the element, } \\
t & =\text { decay time, sec, } \\
T & =\text { irradiation time, sec. }
\end{aligned}
$$

Also,

$$
P_{0}=\frac{\bar{\phi}_{i} w_{i} P^{\prime}}{\bar{\phi}_{c} w_{c}},
$$

where

$\bar{\phi}_{i}=$ average flux in the $i$ th element,

$\bar{\phi}_{c}=$ average flux in the core,

${ }^{3} \mathrm{H}$. Etherington, Nuclear Engineering Handbook, p 7-15, McGraw-Hill, New York, 1958. 
$W_{i}=$ weight of $U^{235}$ in the $i$ th element,

$W_{c}=$ weight of $U^{235}$ in the core,

$P^{\prime}=$ reactor power.

Then since $P \sim Q$ one obtains

$\theta=6.22 \times 10^{-2}\left[t^{-0.2}-(T+t)^{-0.2]} \frac{\bar{\phi}_{i} W_{i} P^{\prime}}{\bar{\phi}_{c .} W_{c}} C_{1}\right.$.

A second method is the use of the beta and gamma decay curves presented by Perkins and King. ${ }^{4}$ The sum of these curves will be referred to as $Y$. It has the dimensions Mev/wsec. It must be multiplied by the element operating power,

$$
\frac{\bar{\phi}_{i} W_{i} P^{\prime}}{\bar{\phi}_{c} W_{c}}
$$

Thus, one finds that

$$
\theta=C_{2} \frac{\bar{\phi}_{i} W_{i} P^{\prime}}{\bar{\phi}_{c} W_{c}} Y
$$

The problem now evolves to that of determining $C_{1}$ and $C_{2}$. Of all the data points available, five represent elements which had only one cycle in the reactor. The $\theta^{\prime}$ s for those five were used to calculate mean values for $C_{1}$ and $C_{2}$. The values found were

$$
\begin{aligned}
& C_{1}=2.2 \times 10^{5}, \\
& C_{2}=4.5 \times 10^{-8} .
\end{aligned}
$$

The assumption is made that the $\theta^{\prime}$ s for all cycles are additive, that is, each cycle is computed as though it were the element's only cycle, and the resultant $\theta^{\prime}$ s are added to give the actual $\theta$ of the element. No proof will be offered except pragmatic. It is obvious that the effect of past cycles becomes more pronounced as the decay time increases. However, even with short decays they often contribute $10 \%$ to $\theta$.

If one divides the calculated $\theta_{c}$ by the measured $\theta_{m}$ one obtains a measure of the error between the

\footnotetext{
4J. F. Perkins and R. W. King, Nuclear Sci. and Eng. 3, 726-46 (1958).
}

two. Figure 8 shows $\theta_{c} / \theta_{m}$ vs $\theta_{c}$. One sees that a systematic error is present and that this error is apparently a function of $\theta$.

Upon re-examining the assumptions previously stated, one finds several sources of error. All the heat is not lost by convection. The hottest elements, that is, those with surface temperatures over $450^{\circ} \mathrm{F}$, will begin to lose noticeable amounts by radiation. An undetermined amount of energy will be released in the side plates due to gamma ray absorption. It is known that for vertical plates suspended in air (e.g., the side plates and exterior fuel plates), the heat transfer coefficient is a function of the temperature difference between the ambient air and the plate surface. ${ }^{5}$ One might then expect that $b \sim a \theta^{n}+b$. Applying such a correction to the data of Fig. 8 , one obtains $a=0.0064, n=0.72, b=0.5$. This leads to the formulations:

$\theta\left(0.0064 \theta^{0.72}+0.5\right)$

$$
=1.37 \times 10^{3}\left[t^{-0.2}-(T+t)^{-0.2}\right] \frac{\bar{\phi}_{i} W_{i} P^{\prime}}{\bar{\phi}_{c} W_{c}}
$$

and

$$
\theta\left(0.0064 \theta^{0.72}+0.5\right)=4.5 \times 10^{-8} \frac{\bar{\phi}_{i} W_{i} P^{\prime}}{\bar{\phi}_{c} W_{c}} Y,
$$

where $Y$ is as previously defined. If one now plots $\theta_{c} / \theta_{m}$ as in Fig. 9, one sees that the systematic error is gone.

By use of standard procedures ${ }^{6}$ one finds that for the Way-Wigner form

$$
\theta_{c} / \theta_{m}=1.091 \pm 0.088
$$

and for the Perkins and King data

$$
\theta_{c} / \theta_{m}=1.055 \pm 0.061 \text {. }
$$

No attempt was made to remove the positive bias since it was felt that on overestimation of temperature was the preferable error.

${ }^{5}$ W. H. McAdams, Heat Transmission, 3d od., p 173, McGraw-Hill, New York, 1954.

${ }^{6}$ W. H. Reddick and F. H. Miller, Advanced Matbematics for Engineers, chap. 9, Wiley, Now York, 1955. 


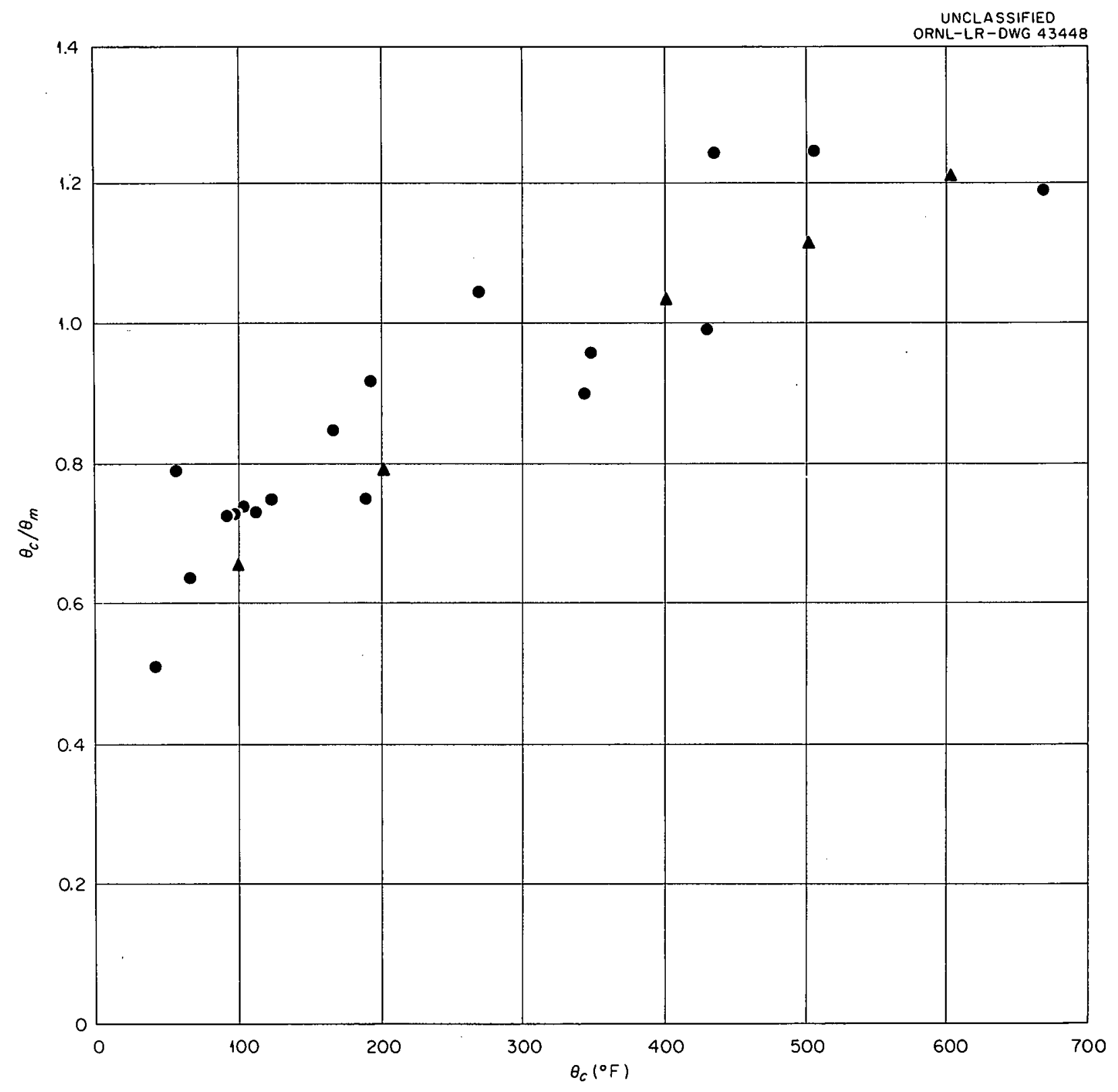

Fig. 8. Variation of $\theta_{c} / \theta_{m^{\prime}}$ Using $b=$ Constant.

ANALYSIS OF ERR ORS

There are two major sources of error inherent in this experiment. The first is the obvious one of experimental error. The second is less obvious. As stated, the objective was to correlate temperatures with reactor history. Thus, the second type of error is that associated with computing and reporting the element's history.

\section{Experimental Error}

The location of the thermocouples within the probes presented some problem. The probes contoining three thermocouples presented more trouble than those containing only one. It is thought that the couples were located within $\pm \frac{1}{4}$ in.

The location of the probes in the elements presents a possible source of error. Out of neces- 


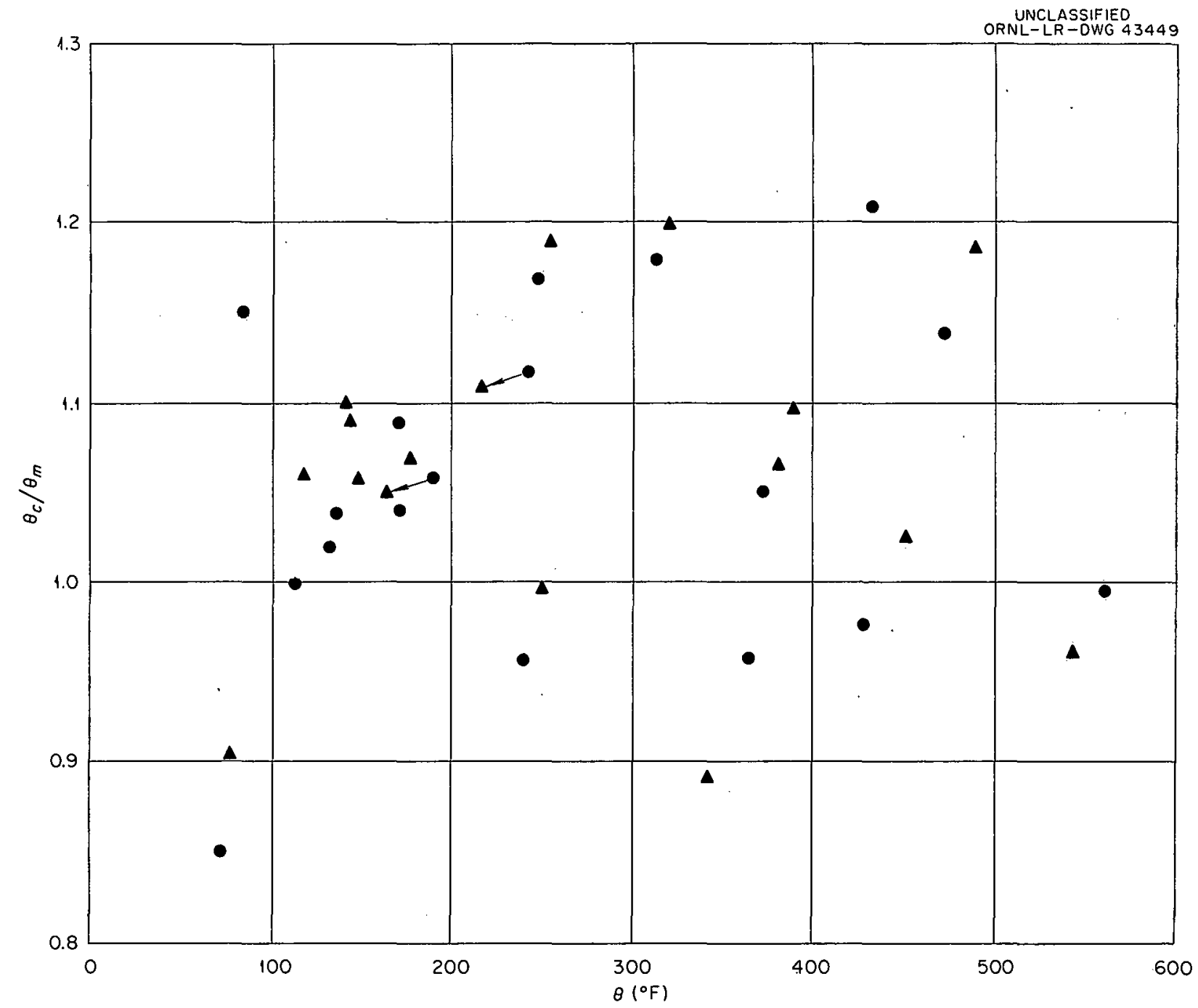

Fig. 9. Variation of $\theta_{c} / \theta_{m^{\prime}}$ Using $b=C\left(0.0064 \theta^{0.72}+0.5\right)$.

sity these probes had to be positioned through $12 \mathrm{ft}$ of water. It is obvious that one could not always measure the same channel. Examination in the hot cell did show that the probes were inserted to the proper datum level.

The friction fit of the probes could lead to false readings. Probes which did not fit tightly were discarded. It is believed that the measured equilibrium temperatures closely approximated those of the adjacent plates.

The presence of the probes undoubtedly perturbed the air flow and hence the temperatures. The magnitude of this error is unknown.

Normal errors associated with recorders and the taking of data were undoubtedly present.

\section{Historical Errors}

Measurement of flux may easily have been in error by $15 \%{ }^{7}$

The power of the reactor fluctuates and may for considerable periods be 1 or $2 \%$ different from the nominal.

Weights of fuel elements (except for new ones) and of cores are calculated by use of measured fluxes. Hence, one might easily obtain a compounding of the flux uncertainty.

7R. J. Nertney, The First Report of the Heat Transfer Subcommittee of the Pbillips Reactor Saleguard Committee, IDO-16343 (June 1, 1957). 


\section{EFFECTS OF PARTIAL SUBMERGENCE IN WATER}

The MSA Research Corporation has done research on cooling a' stainless steel subassembly similar in construction to an ORR element. ${ }^{8}$ The subassembly was heated by induction at rates of 260 and 600 Btu.hr ${ }^{-1} \cdot$ in. $^{-3}$. MSA found that temperatures rose uncontrollably when the subassembly was less than $30 \%$ submerged in water. When the subassembly was more than $30 \%$ sub-: merged, water "percolated" up the channels, cooling the plates.

Partial-submergence checks were run on OR-158 and OR-164. Element OR-158 was generating heat at $\sim 6$ Btu.hr ${ }^{-1}$. in. ${ }^{-3}$, and no rise in temperature was observed at any point during the submerging process. Data for OR-158 are shown in Fig. 10.

${ }^{8}$ M. J. McGoff, Subassembly Cooling at Decay Heat Power Levels, MSAR-59-78 (July 17, 1959).
Element OR-164 was generating heat at a rate of 111 Btu.hr-1.in. ${ }^{-3}$. When the element was lowered so that the fuel plates just touched the water, a sudden rise in temperature was noticed. However, the rise did not get out of control, but the temperature oscillated at a point lower than the original. The couples farthest from the water showed the most oscillation. As the element was lowered farther, the oscillations damped out until the temperatures behaved similarly to those of OR-158. No transport of water up the channelis was observed. Data for OR-164 are shown in Fig. 11 .

\section{SUMMARY AND DISCUSSION}

It can evidently be concluded that an ORR element can be safely cooled in stagnant air after a decay of $19 \mathrm{hr}$. It seems reasonable to suspect that the decay period could be safely extrapolated to $12 \mathrm{hr}$.

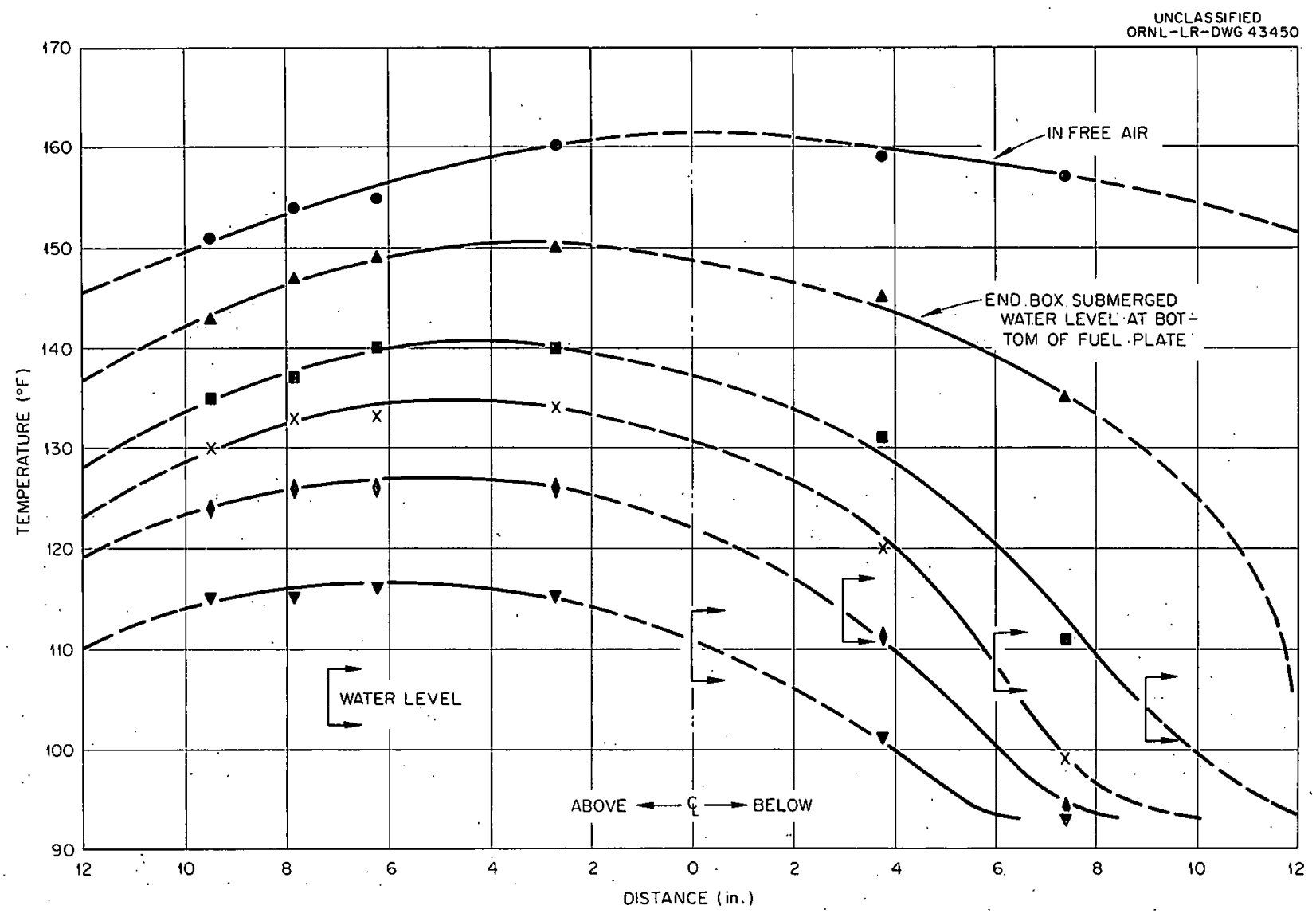

Fig. 10. Effect of Partially Submerging OR-158 in Water. 


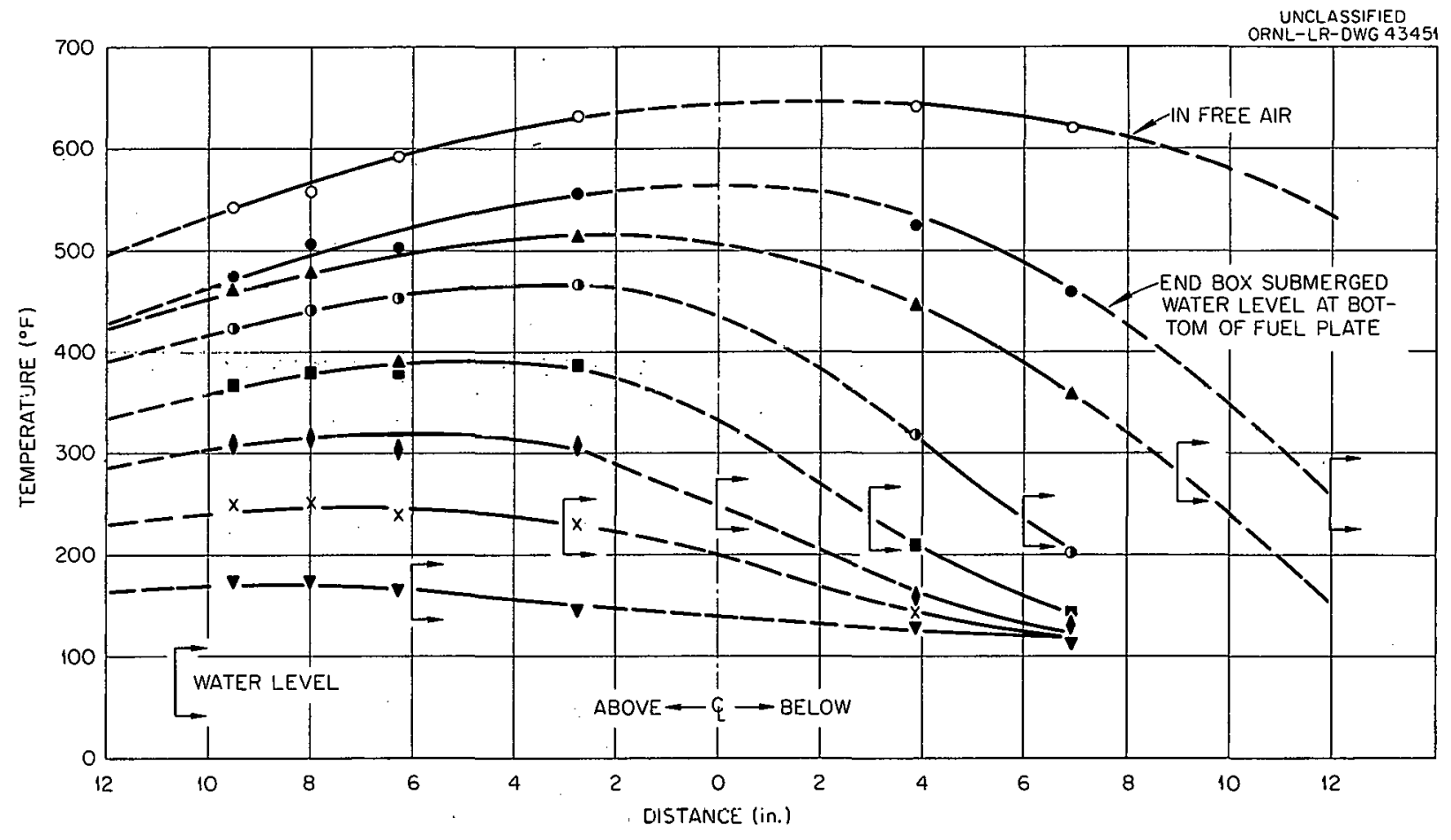

Fig. 11. Effect of Partially Submerging OR-164 in Water.

Two correlations between surface temperature and irradiation history hove been developed. One uses the Way-Wigner equation to determine the heat source, the other uses the data of Perkins and King. They are

$$
\theta\left(0.0064 \theta^{0.72}+0.5\right)=1.37 \times 10^{3}\left[t^{-0.2}-(T+t)^{-0.2}\right] \frac{\bar{\phi}_{i} W_{i} P^{\prime}}{\bar{\phi}_{c} W_{c}}
$$

and

$$
\theta\left(0.0064 \theta^{0.72}+0.5\right)=4.5 \times 10^{3} \frac{\bar{\phi}_{i} w_{i} P^{\prime}}{\bar{\phi}_{c} w_{c}} Y,
$$

where the terms are defined in the text.

Temperatures measured during the partial submergence of fuel elements strongly indicate that there probably is a power density above which partial submergence causes higher temperature than no submergence at all. It is noted that the surface temperatures in OR-164 were above the boiling point at some distance $\left(\sim \frac{1}{2} \mathrm{in}\right.$.) below the water surface. It is suspected that boiling occurred in the channels. It is believed that the boiling, a rapid vaporization of water, and the heat-sink characteristics of the pool kept the temperatures frum rising uncontrollably. 
THIS PAGE

\section{WAS INTENTIONALLY \\ LEFT BLANK}


I. C. E. Center

2. Biology Library

3. Health Physics Library

4-5. Central Research Library

6. Reactor Experimental Engineering Library

7-26. Laboratory Records Department

27. Laboratory Records, ORNL R.C.

28. A. M. We inberg

29. L. B. Emlet (K-25)

30. J. P. Murray $(Y-12)$

31. J. A. Swartout

32. E. H. Taylor

33. E. D. Shipley

34. S. C. Lind

35. M. L. Nelson

36. C. P. Keim

37. J. H. Frye, Jr.

38. R. S. Livingston

39. F. L. Culler

40. A. H. Snell

41. A. Hollaender

42. M. T. Kelley

43. K. Z. Morgan

44. T. A. Lincoln

45. A. S. Householder

46. C. S. Harrill

47. C. E. Winters

48. H. E. Seagren

49. D. Phillips

50. D. S. Billington

51. J. A. Lane

52. M. J. Skinner

53. W. H. Jordan

54. G. E. Boyd
55. R. A. Charpie

56. P. M. Reyling

57. R. S. Cockreham

58. G. C. Williams

59. F. T. Binford

60. E. P. Blizard

61. R. B. Briggs

62. C. D. Cagle

63. W. R. Casto

64. T. E. Cole

65. A. L. Colomb

66. B. L. Corbett

67. W. B. Cottrell

68. E. Cramer

69. G. A. Cristy

70. J. A. Cox

71. E. P. Epler

72. O. Freeland

73. C. B. Gaither

74. S. S. Hurt, III

75. V. J. Kelleghan

76. H. V. Klaus

77. F. C. Maienschein

78. R. V. MeCord

79. F. H. Neill

80. A. R. Olsen

81. M. E. Ramsey

82. A. F. Rupp

83. T. M. Sims

84. L. E. Stanford

85. W. H. Tabor

86. A. A. Walls

87-102. J. F. Wett, Jr.

103. ORNL - Y-12 Technical Library, Document Reference Library

\section{EXTERNAL DISTRIBUTION}

104. Division of Research and Development, AEC, ORO

105. A. Boynton, Dept. of Nuclear Engineering, University of Florida

106-110. C. Osborne, Brookhaven National Laboratory

111-112. National Reactor Test Station, Arco (J. Rainwater and V. Walker)

113-568. Given distribution as shown in TID-4500 (15th ed.) under Equipment, Methods, and

Techniques category (75 copies - OTS) 